Ekonomia - Wroclaw Economic Review 24/2 (2018)

Acta Universitatis Wratislaviensis

No 3858

DOI: $10.19195 / 2084-4093.24 .2 .2$

Adam Łukojć

ORCID: 0000-0002-0937-8195

Akademia Leona Koźmińskiego w Warszawie

adam.lukojc@interia.pl

Iwona Białomazur

ORCID: 0000-0002-3757-8805

Szkoła Główna Handlowa w Warszawie

yvonne.b@op.pl

\title{
Analiza wpływu wybranych czynników na popyt na usługę zarządzania funduszem inwestycyjnym
}

Artykuł nadesłany: 31 stycznia 2018 r.; artykuł zaakceptowany: 20 kwietnia 2018 r.

JEL Classification: G11, G23

Keywords: mutual fund, investment decision, management fee

\begin{abstract}
Analysis of the impact of selected determinants on the demand for mutual fund management services
\end{abstract}

The authors try to identify the main factors impacting the value of inflows to mutual funds in Poland. The inflows to mutual funds are compared to the following data: costs (total expense ratios), investment performance in the current and previous year, and fund size. The data was collected from 451 financial statements of Polish mutual funds, for the years 2012-2016. The funds belong to three categories: bond, equity, small, and mid cap equity. The findings suggest that the connection between the funds fees - the price - and inflows to funds is relatively weak. Investment performance in the same year is the only factor that shows significant correlation with mutual fund flows.

\section{Wstęp}

Wyższa cena oznacza niższy popyt — mówi o tym prawo popytu i podaży. Jednak o popycie na poszczególne dobra decydują również inne czynniki, na przykład 
jakość. Znaczenie czynników innych niż cena może być jednak czasami trudne do zmierzenia - w wypadku wielu produktów czy usług nie istnieje ilościowa miara jakości danego dobra.

Jednym z wyjątków może być usługa zarządzania funduszami inwestycyjnymi. W tym przypadku istnieją parametry, które można wiązać z jakością i które można próbować oszacować, między innymi znana klientom stopa zwrotu osiągnięta przez dany fundusz. Nawet zakładając ograniczoną racjonalność klientów, popyt na usługę zarządzania funduszami inwestycyjnymi powinien zależeć głównie od czynników ilościowych - w przeciwieństwie do popytu na przykład na lodówki czy usługi fryzjerskie, w wypadku których znaczenie mogą mieć takie czynniki, jak wygląd produktu lub miejsce świadczenia usługi. Tymi czynnikami mogą być:

a) cena - wynagrodzenie za zarządzanie pobierane przez towarzystwo funduszy inwestycyjnych zarządzające danym funduszem;

b) osiągnięta stopa zwrotu (w różnych okresach);

c) wartość aktywów netto zgromadzonych przez dany fundusz - z jednej strony, bycie uczestnikiem funduszu o względnie wysokich aktywach może dawać klientowi poczucie bezpieczeństwa - inni klienci również uwierzyli w ten produkt finansowy; $z$ drugiej strony, obiegowa opinia mówi o tym, że funduszom o relatywnie niskich aktywach łatwiej jest osiągać ponadprzeciętne stopy zwrotu;

d) poziom ryzyka związany $\mathrm{z}$ inwestycją $\mathrm{w}$ dany fundusz - wyższe ryzyko powinno zniechęcać do inwestowania $\mathrm{w}$ dany fundusz, przy pozostałych cechach niezmienionych; wpływ ryzyka nie był jednak analizowany w niniejszym badaniu, gdyż porównano w nim fundusze o podobnej polityce inwestycyjnej, a więc i o zbliżonym poziomie ryzyka.

Powstaje pytanie, jakie znaczenie dla popytu na usługę zarządzania danym funduszem ma cena tej usługi. Można jednocześnie zastanowić się, jak istotne są inne czynniki. Autorzy niniejszego tekstu podejmują próbę oszacowania wpływu wymienionych czynników na popyt na usługę zarządzania danym funduszem inwestycyjnym. Celem badania jest określenie, w jaki sposób inwestorzy traktują fundusze inwestycyjne. Autorzy stawiają hipotezę, że dla uczestników polskich funduszy inwestycyjnych cena ma mniejsze znaczenie niż czynniki związane z jakością usługi.

Badanie zostało przeprowadzone na próbie obejmującej polskie fundusze: obligacji, akcji polskich oraz akcji małych i średnich spółek. Wykorzystano w nim dane za lata 2012-2016, zebrane między innymi z 451 sprawozdań finansowych.

\section{Dotychczasowe badania}

Zagadnienie sposobu podejmowania decyzji przez uczestników funduszy inwestycyjnych nie zostało przebadane tak dokładnie jak na przykład podejmowanie 
decyzji inwestycyjnych przez osoby zarządzające tymi funduszami. W dodatku wnioski płynące z nielicznych badań nad zachowaniem uczestników funduszy inwestycyjnych nie są optymistyczne dla klientów firm zarządzających.

Doradcy finansowi mają wpływ na decyzje swoich klientów, zachęcają ich bowiem do podążania za przeszłymi stopami zwrotu osiągniętymi w krótkim terminie (O’Neal 2004). Cashman et al. zauważają, że związek między osiągniętymi stopami zwrotu a napływami do funduszy nie jest liniowy — klienci chętnie nagradzają fundusze o nadzwyczajnie dobrych wynikach i karzą te, które miały wyjątkowo kiepskie rezultaty (Cashman et al. 2012). Taka strategia nie prowadzi do najbardziej efektywnych decyzji. Christoffersen et al. (2013) zadają pytanie „Co maksymalizują napływy od klientów?” (,What do consumers' fund flows maximize?") i w swoim badaniu odpowiadają: przede wszystkim klienci maksymalizują przychody firm, które sprzedają im jednostki funduszy inwestycyjnych.

Wycofywanie kapitału z funduszy, które odnotowały straty, może mieć uzasadnienie podatkowe - inwestorzy mogą chcieć zrealizować stratę podatkową. Ivković i Weisbenner (2009) zauważają różnice w zachowaniu inwestorów w zależności od ich sytuacji podatkowej. Z kolei Christoffersen i Xu (2017) odkrywają, że część inwestorów nie wycofuje kapitału z funduszy, które wybrali, niezależnie od tego, jakie wyniki osiąga dany fundusz.

Frazzini i Lamont (2008) badają skutki decyzji inwestorów o doborze funduszy, podejmowanych w latach 1980-2003. Zauważają, że klienci przenoszą swoje aktywa między poszczególnymi funduszami w niekorzystny dla nich sposób. Natomiast Zheng (1999) w tytule swojego artykułu z 1999 roku zadaje pytanie o racjonalność inwestorów: „Czy pieniądz jest inteligentny? Badanie zdolności doboru funduszy przez inwestorów w funduszach inwestycyjnych” („Is money smart? A study of mutual fund investors' fund selection ability"); Frazzini i Lamont odpowiadają: „,napływy do funduszy to głupi pieniądz” (,fund flows are dumb money”) (Frazzini, Lamont 2008, s. 299). Korelacja stopy zwrotu z napływami do funduszu jest, ich zdaniem, dodatnia w okresie trzech miesięcy, lecz ujemna w okresach od sześciu miesięcy do trzech lat (Frazzini, Lamont 2008, s. 307).

Zbadano także wpływ płci zarządzającego na wielkość funduszu. W badaniu przeprowadzonym przez Alexandrę Niessen-Ruenzi i Stefana Ruenzi okazało się, że fundusze zarządzane przez kobiety otrzymują niższe napływy netto niż fundusze zarządzane przez mężczyzn. Napływy do tych pierwszych były niższe o 35-50\% (w zależności od użytego przez badaczy modelu kalkulacji). Wpływ zmiennej określającej płeć okazał się mieć istotne znaczenie ekonomiczne (Niessen-Ruenzi, Ruenzi 2018).

Dotychczas badacze zajmowali się głównie rynkiem amerykańskim. Amerykański rynek funduszy inwestycyjnych jest nie tylko największy na świecie, lecz także dane pochodzące z niego są najbardziej dostępne. Wśród potencjalnych determinant napływów do amerykańskich funduszy zbadano nawet, czy osoba zarządzająca funduszem nosi typowo amerykańskie, czy zagranicznie brzmiące 
nazwisko (Kumar et al. 2015). Ferreira et al. (2012) zauważają jednak, że zachowanie uczestników funduszy inwestycyjnych różni się pomiędzy krajami; trzeba pamiętać, że wnioski, do których doszli badacze zajmujący się innymi rynkami, nie muszą mieć zastosowania w Polsce.

\section{Bieżące uwarunkowania}

Zgodnie z ustawą o funduszach inwestycyjnych każdy fundusz musi mieć swój statut. Dokument ten określa wysokość opłat oraz wskazuje, które koszty są pokrywane przez fundusz inwestycyjny, a które przez towarzystwo funduszy inwestycyjnych. Jednak wysokość wynagrodzenia za zarządzanie wskazana w statucie - na przykład w wypadku funduszy polskich akcji zwykle równa 4\% wartości aktywów netto funduszu — rzadko odpowiada wysokości kosztów ponoszonych przez uczestników. Towarzystwo funduszy inwestycyjnych może pobierać opłatę mniejszą od określonej w statucie; może też pokryć część kosztów, które poniósł fundusz. Towarzystwo funduszy inwestycyjnych może w ten sposób próbować zachęcić potencjalnych klientów do wybrania danego funduszu, a więc może chcieć, żeby fundusz osiągnął możliwie najwyższą stopę zwrotu - nawet kosztem okresowego obniżenia przychodów firmy (tę strategię, nazwaną inkubacją funduszu, bada między innymi Evans 2010).

Jednocześnie fundusz może ponosić liczne inne koszty niż wynagrodzenie za zarządzanie, takie jak chociażby opłaty dla depozytariusza, koszty wyceny funduszu czy koszty usług bankowych; z punktu widzenia klienta te koszty są częścią ceny płaconej za usługę zarządzania funduszem. Klient nie zna jednak ich wysokości - może najwyżej spodziewać się pewnego ich poziomu na podstawie przeszłych danych finansowych funduszu (sprawozdania finansowe funduszy inwestycyjnych otwartych są publikowane raz na pół roku).

Pytanie o motywacje klientów wybierających produkty finansowe jest istotne szczególnie teraz, w okresie wprowadzania zmian w przepisach dotyczących informowania o opłatach i pobierania opłat za zarządzanie funduszami inwestycyjnymi. Parlament Europejski 15 kwietnia 2014 roku przyjął bowiem dyrektywę 2014/65/EU dotyczącą funkcjonowania rynków instrumentów finansowych. Nowa dyrektywa ma doprowadzić między innymi do uregulowania sposobu pobierania opłat przez towarzystwa funduszy inwestycyjnych oraz zwiększyć świadomość klientów (uczestników funduszy) na temat tego, komu i ile płacą za usługi doradztwa finansowego i zarządzania aktywami. Argumentem za wprowadzeniem nowych przepisów jest niska wiedza klientów o pobieranych opłatach. Na przykład Christoffersen et al. (2013) zauważają dodatnią korelację między napływami do funduszy inwestycyjnych a wysokością wynagrodzenia dystrybutora funduszy - im bardziej hojnie firma zarządzająca funduszami dzieli się opłatami z podmiotami sprzedającymi fundusze, tym wyższe aktywa przyciąga dany fun- 
dusz; może to świadczyć o rekomendowaniu klientom tych funduszy, które wiążą się z ponadprzeciętnie wysokimi opłatami.

Sposób wdrożenia dyrektywy w Polsce wywołał dyskusję, zwłaszcza po tym jak Komisja Nadzoru Finansowego zaproponowała wprowadzenie prawnego ograniczenia wysokości pobieranych opłat. Argumentem za obniżeniem opłat była wysokość wynagrodzenia za zarządzanie, która w Polsce przekracza poziom opłat w innych krajach. Ferreira et al. zbadali fundusze akcji z 27 krajów i odkryli, że w latach 2000-2007 to właśnie w Polsce usługa zarządzania była najdroższa (Ferreira et al. 2013, s. 492). Polskie fundusze otwarte inwestujące w akcje płacą towarzystwu funduszy inwestycyjnych zwykle 4\% wartości aktywów netto funduszu, podczas gdy w Stanach Zjednoczonych średnia wysokość wynagrodzenia za zarządzanie funduszami akcji wyniosła w 2010 roku 0,909\% (Malkiel 2013, s. 99). Wysokość opłat jest krytykowana przede wszystkim przez osoby wierzące w efektywność rynków finansowych, zwłaszcza teoretyków - na przykład Mishkin podaje przykład zabawy prowadzonej przez „San Francisco Chronicle”: małpa losuje spółki notowane na giełdzie i po założonym okresie porównuje się wyniki tego losowania z rekomendacjami profesjonalnych analityków (Mishkin 2002, s. 865).

Przeciwnicy ingerencji regulatora $\mathrm{w}$ wysokość pobieranych opłat - czyli między innymi przedstawiciele sektora usług finansowych — radzą, żeby pozostawić ustalenie ceny wolnemu rynkowi. Bogle zauważa, że mimo rosnącej konkurencji cena usługi aktywnego zarządzania funduszami inwestycyjnymi w Stanach Zjednoczonych wzrosła od 1951 roku do 2012 roku o 84\% (Bogle 2013, s. 139). Khorana et al. odkrywają z kolei istotne różnice w poziomie opłat między poszczególnymi krajami, wskazując, że wnioski z badania przeprowadzonego w jednym kraju nie muszą tłumaczyć zachowania inwestorów z innego państwa (Khorana et al. 2009).

W niniejszym artykule podjęto próbę zbadania związku napływów do funduszy inwestycyjnych (czyli sprzedaży usługi zarządzania funduszami) z trzema czynnikami ilościowymi: wysokością kosztów ponoszonych przez dany fundusz, stopą zwrotu z danego funduszu i wartością aktywów netto danego funduszu. Zbadano fundusze: akcji polskich, akcji małych i średnich spółek oraz obligacji. Badaniem objęto lata 2012-2016.

\section{Próba badawcza}

Izba Zarządzających Funduszami i Aktywami (IZFiA) — organizacja branżowa zrzeszająca towarzystwa funduszy inwestycyjnych — co miesiąc publikuje informacje o wartości aktywów netto zgromadzonych w poszczególnych funduszach inwestycyjnych. Dane dotyczą także funduszy zarządzanych przez towarzystwa, które nie należą do IZFiA. 
IZFiA dzieli fundusze na grupy na podstawie kryterium stosowanej przez fundusz polityki inwestycyjnej. Do badania wybrano trzy grupy składające się z funduszy, które inwestują głównie w Polsce; fundusze inwestujące głównie za granicą są trudne do porównania ze względu na trudność w zbudowaniu odpowiednio licznej grupy funduszy o podobnej polityce inwestycyjnej. Dodatkowo fundusze lokujące aktywa poza Polską często inwestują za pośrednictwem innych funduszy, co utrudnia ocenę kosztów ponoszonych przez klienta. Dlatego skoncentrowano się na względnie licznych grupach:

a) funduszy akcji polskich — z której wyłączono fundusze inwestujące głównie poza Polską oraz fundusze zajmujące krótkie pozycje;

b) funduszy akcji polskich małych i średnich spółek - grupa najmniej liczna z wybranych trzech, ale najbardziej homogeniczna;

c) funduszy obligacji — do której włączono fundusze „uniwersalne” oraz „obligacji skarbowych” inwestujące w Polsce.

Z wszystkich grup wyłączono fundusze inwestujące za pośrednictwem innych funduszy oraz fundusze zamknięte.

Na koniec każdego roku, w latach 2012-2016, zebrano dane o:

a) stopie zwrotu $z$ danego funduszu za dany rok (w przypadkach gdy dany fundusz miał więcej niż jedną kategorię jednostek uczestnictwa, wybrano kategorię dostępną dla klientów detalicznych, obciążoną najwyższymi opłatami);

b) wartości aktywów netto funduszu na koniec roku;

c) kosztach poniesionych przez uczestników funduszu w danym roku.

Wymienione zmienne potraktowano jako zmienne objaśniające.

Wzięto również pod uwagę, że sytuacja panująca na rynkach kapitałowych w określonym momencie może wpływać na determinanty napływów do funduszy inwestycyjnych (Shrider 2009). W badaniu wykorzystano dane pochodzące z pięciu lat i z trzech różnych grup funduszy, aby zminimalizować ten wpływ na wyniki badania.

Dane o kosztach pochodzą ze sprawozdań finansowych funduszy. Dane o stopach zwrotu - z publicznie dostępnych źródeł: stron internetowych towarzystw funduszy inwestycyjnych lub ze sprawozdań finansowych funduszy. Natomiast dane o wartości aktywów netto - z raportów IZFiA. Zebranie danych wymagało przejrzenia 451 sprawozdań finansowych funduszy i było najbardziej czasochłonną częścią badania.

Wartość kosztów poniesionych przez uczestników funduszy została obliczona na podstawie danych z rocznych sprawozdań finansowych funduszy. Całkowite koszty poniesione przez fundusz zostały pomniejszone o koszty wynikające z działalności inwestycyjnej: koszty odsetkowe i ujemne saldo różnic kursowych. W ten sposób w porównaniu uwzględniono wynagrodzenie dla towarzystwa funduszy inwestycyjnych oraz koszty związane z technicznymi aspektami działalności (czyli koszty, które w wypadku niektórych funduszy są pokrywane przez towarzystwo, a nie fundusz). Tabela 1 przedstawia fragment rachunku wyników $\mathrm{z}$ operacji jednego $\mathrm{z}$ badanych funduszy. 
Tabela 1. Fragment rachunku wyników z operacji funduszu Quercus Agresywny za 2016 rok (dane w tys. PLN)

\begin{tabular}{r|l|r}
\hline \multicolumn{1}{|c|}{ II. Koszty funduszu } & 20261 \\
\hline 1. & Wynagrodzenie dla towarzystwa & 18635 \\
\hline 2. & Wynagrodzenie dla podmiotów prowadzących dystrybucję & 0 \\
\hline 3. & Opłaty dla depozytariusza & 92 \\
\hline 4. & Opłaty związane z prowadzeniem rejestru aktywów funduszu & 147 \\
\hline 5. & Opłaty za zezwolenia oraz rejestracyjne & 0 \\
\hline 6. & Usługi w zakresie rachunkowości & 109 \\
\hline 7. & Usługi w zakresie zarządzania aktywami funduszu & 0 \\
\hline 8. & Usługi prawne & 1 \\
\hline 9. & Usługi wydawnicze, w tym poligraficzne & 0 \\
\hline 10. & Koszty odsetkowe & 0 \\
\hline 11. & Koszty związane z posiadaniem nieruchomości & 0 \\
\hline 12. & Ujemne saldo różnic kursowych & 906 \\
\hline 13. & Pozostałe & 371 \\
\hline & & 0 \\
\hline
\end{tabular}

Źródło: Sprawozdanie finansowe Quercus SFIO za 2016 rok, s. 123.

Całkowite koszty zostały pomniejszone o koszty pokrywane przez towarzystwo funduszy inwestycyjnych.

Należy w tym miejscu także dodać, że częścią sprawozdania finansowego funduszu jest ,zestawienie zmian w aktywach netto”. Zawiera ono informację o procentowym udziale kosztów funduszu w średniej wartości aktywów netto. Wartość ta uwzględnia jednakże koszty wynikające z działalności inwestycyjnej.

Tabela 2. Fragment zestawienia zmian w aktywach netto funduszu Quercus Agresywny za 2016 rok

\begin{tabular}{c|l|c}
\hline \multicolumn{2}{l|}{ IV. Procentowy udział kosztów funduszu w średniej wartości aktywów netto, w tym: } & 3,59 \\
\hline 1. & Procentowy udział wynagrodzenia dla towarzystwa & 3,31 \\
\hline 2. & Procentowy udział wynagrodzenia dla podmiotów prowadzących dystrybucję & - \\
\hline 3. & Procentowy udział opłat dla depozytariusza & 0,02 \\
\hline 4. & Procentowy udział opłat związanych z prowadzeniem rejestru aktywów funduszu & 0,03 \\
\hline 5. & Procentowy udział opłat za usługi w zakresie rachunkowości & 0,02 \\
\hline 6. & Procentowy udział opłat za usługi w zakresie zarządzania aktywami funduszu & - \\
\hline \multicolumn{3}{c}{ Źródło: Sprawozdanie finansowe Quercus SFIO za 2016 rok, s. 124. } \\
\hline \\
W Średniej wartości aktywów netto”, skorygowane o: koszty odsetkowe, ujemne
\end{tabular}


saldo różnic kursowych, i koszty pokrywane przez TFI. W przykładzie danych za 2016 rok dla funduszu Quercus Agresywny przedstawia się to następująco:

$$
(20261-906): 20261 \times 3,59 \%=3,43 \% \text {. }
$$

Dane dotyczące stóp zwrotu i wartości aktywów netto nie wymagały dodatkowych obliczeń.

Dodatkowych operacji wymagały natomiast zmienne objaśniane. W badaniu zmiennymi objaśnianymi są:

a) zmiana wartości aktywów netto funduszu wynikająca z napływu klientów (wyrażona w złotych) — czyli kwota, o którą zwiększył się fundusz w wyniku pozyskania nowych klientów-inwestorów;

$\beta)$ procentowa zmiana wartości aktywów netto funduszu wynikająca $\mathrm{z}$ napływu klientów.

IZFiA nie publikuje danych o napływach nowych aktywów do poszczególnych funduszy. Kwoty napływów można próbować oszacować na podstawie danych o wartości aktywów netto na końcu każdego roku i o stopie zwrotu z funduszu w danym roku. W badaniu założono, że klienci dokonali wszystkich wpłat i wypłat w ostatnim dniu roku — przyjęcie tego założenia umożliwiło oddzielenie wpływu stopy zwrotu od wpływu wpłat i wypłat na wartość aktywów netto funduszu. Wartość napływów w danym roku oszacowano na podstawie wzoru:

$$
\mathrm{WAN}_{\mathrm{n}}-\mathrm{WAN}_{\mathrm{n}-1} \times\left(1+\mathrm{r}_{\mathrm{n}}\right)
$$

gdzie:

WAN $_{\mathrm{n}}$ - wartość aktywów netto na koniec roku n,

WAN $_{\mathrm{n}-1}$ - wartość aktywów netto na koniec roku n-1, $\mathrm{r}_{\mathrm{n}}$ - stopa zwrotu $\mathrm{z}$ funduszu w roku $\mathrm{n}$.

\section{Hipotezy i procedura badawcza}

Dla każdego roku i dla każdego rodzaju funduszy przeprowadzono osobne badania. Dla danego roku i dla danego rodzaju funduszy każdy fundusz w grupie został scharakteryzowany przez cztery dane objaśniające:

1. procentowy udział kosztów funduszu w średniej wartości aktywów netto za poprzedni rok,

2. wartość aktywów netto na koniec poprzedniego roku,

3. stopę zwrotu z funduszu za poprzedni rok,

4. stopę zwrotu $\mathrm{z}$ funduszu za dany rok. 
Dla każdej grupy przeprowadzono dwa osobne badania, różniące się zmienną objaśnianą. Zmienną objaśnianą była:

a) zmiana wartości aktywów netto wynikająca z napływu klientów (w PLN),

b) procentowa zmiana wartości aktywów netto funduszu wynikająca z napływu klientów.

Postawiono następujące hipotezy:

1. Koszty poniesione przez dany fundusz w poprzednim roku nie miały wpływu na napływ klientów (wyrażony w PLN) do funduszu w danym roku.

2. Stopa zwrotu $z$ danego funduszu osiągnięta $w$ poprzednim roku nie miała wpływu na napływ klientów (wyrażony w PLN) do funduszu w danym roku.

3. Stopa zwrotu $z$ danego funduszu osiągnięta w danym roku nie miała wpływu na napływ klientów (wyrażony w PLN) do funduszu w tym samym roku.

4. Wielkość funduszu (wartość aktywów netto) na koniec poprzedniego roku nie miała wpływu na napływ klientów (wyrażony w PLN) do funduszu w tym samym roku.

5. Koszty poniesione przez dany fundusz w poprzednim roku nie miały wpływu na napływ klientów (wyrażony jako udział w aktywach netto funduszu na koniec poprzedniego roku) do funduszu w danym roku.

6. Stopa zwrotu $\mathrm{z}$ danego funduszu osiągnięta w poprzednim roku nie miała wpływu na napływ klientów (wyrażony jako udział w aktywach netto funduszu na koniec poprzedniego roku) do funduszu w danym roku.

7. Stopa zwrotu $z$ danego funduszu osiągnięta $w$ danym roku nie miała wpływu na napływ klientów (wyrażony jako udział w aktywach netto funduszu na koniec poprzedniego roku) do funduszu w tym samym roku.

8. Wielkość funduszu (wartość aktywów netto) na koniec poprzedniego roku nie miała wpływu na napływ klientów (wyrażony jako udział w aktywach netto funduszu na koniec poprzedniego roku) do funduszu w tym samym roku.

W każdym badaniu wartości zarówno zmiennych objaśniających, jak i zmiennej objaśnianej uszeregowano w kolejności. Tabela 3 przedstawia przykład: grupę funduszy akcji małych i średnich spółek w badaniu za 2016 rok. 
Tabela 3. Dane dotyczące funduszy akcji małych i średnich spółek

\begin{tabular}{|c|c|c|c|c|c|c|}
\hline \multirow[b]{2}{*}{ Nazwa funduszu } & \multicolumn{2}{|c|}{ Koszty } & \multicolumn{2}{|c|}{ Aktywa netto } & \multicolumn{2}{|c|}{ Napływ aktywów } \\
\hline & $\begin{array}{c}\text { Wartość } \\
{[\%]}\end{array}$ & Ranga & Wartość & Ranga & $\begin{array}{c}\text { Wartość } \\
{[\%]}\end{array}$ & Ranga \\
\hline $\begin{array}{l}\text { Allianz Akcji Małych i Średnich } \\
\text { Spółek }\end{array}$ & 4,01 & 7 & 131,9 & 11 & $-17,7$ & 9 \\
\hline $\begin{array}{l}\text { Amundi Akcji Małych i Średnich } \\
\text { Spółek }\end{array}$ & 4,08 & 11 & 27,5 & 5 & $-57,1$ & 19 \\
\hline Aviva Investors Małych Spółek & 4,04 & 9 & 187,8 & 14 & $-16,0$ & 6 \\
\hline $\begin{array}{l}\text { AXA Akcji Małych i Średnich } \\
\text { Spółek }\end{array}$ & 4,13 & 13 & 63,6 & 6 & 31,0 & 1 \\
\hline BPH Akcji Dynamicznych Spółek & 4,06 & 10 & 152,4 & 13 & $-14,4$ & 3 \\
\hline Investor Top 25 Małych Spółek & 3,84 & 4 & 193,2 & 15 & $-25,8$ & 13 \\
\hline $\begin{array}{l}\text { IPOPEMA Małych i Średnich } \\
\text { Spółek }\end{array}$ & 4,46 & 17 & 17,3 & 4 & $-61,7$ & 20 \\
\hline $\begin{array}{l}\text { KBC Akcji Małych i Średnich } \\
\text { Spółek }\end{array}$ & 4,40 & 16 & 80,7 & 8 & $-52,0$ & 18 \\
\hline $\begin{array}{l}\text { KBC Portfel Akcji Średnich } \\
\text { Spółek }\end{array}$ & 6,05 & 21 & 9,0 & 1 & $-64,6$ & 21 \\
\hline Metlife Akcji Małych Spółek & 3,59 & 2 & 12,4 & 2 & $-17,2$ & 7 \\
\hline Metlife Akcji Średnich Spółek & 4,26 & 15 & 77,3 & 7 & $-12,9$ & 2 \\
\hline Millennium Dynamicznych Spółek & 4,21 & 14 & 112,0 & 10 & $-22,2$ & 11 \\
\hline NN (PL) Średnich i Małych Spółek & 3,53 & 1 & 295,6 & 19 & $-18,5$ & 10 \\
\hline $\begin{array}{l}\text { Noble Fund Małych i Średnich } \\
\text { Spółek }\end{array}$ & 5,85 & 20 & 347,5 & 20 & $-24,7$ & 12 \\
\hline $\begin{array}{l}\text { Open Finance Małych i Średnich } \\
\text { Spółek }\end{array}$ & 5,79 & 19 & 17,2 & 3 & $-43,4$ & 17 \\
\hline Pioneer Dynamicznych Spółek & 3,70 & 3 & 245,5 & 17 & $-39,1$ & 15 \\
\hline $\begin{array}{l}\text { Pioneer MiŚ Spółek Rynku Pol- } \\
\text { skiego }\end{array}$ & 3,98 & 6 & 228,0 & 16 & $-15,2$ & 4 \\
\hline $\begin{array}{l}\text { PKO Akcji Małych i Średnich } \\
\text { Spółek }\end{array}$ & 4,03 & 8 & 359,7 & 21 & $-39,8$ & 16 \\
\hline $\begin{array}{l}\text { PZU Akcji Małych i Średnich } \\
\text { Spółek }\end{array}$ & 3,96 & 5 & 104,0 & 9 & $-15,8$ & 5 \\
\hline Skarbiec Małych i Średnich Spółek & 5,17 & 18 & 144,4 & 12 & $-17,3$ & 8 \\
\hline $\begin{array}{l}\text { UniAkcje Małych i Średnich } \\
\text { Spółek }\end{array}$ & 4,09 & 12 & 248,1 & 18 & $-28,0$ & 14 \\
\hline
\end{tabular}

Dane do badania za 2016 rok: wartość kosztów poniesionych w 2015 roku, aktywa netto na koniec 2015 roku, napływ aktywów w 2016 roku.

Źródło: opracowanie własne na podstawie sprawozdań funduszy. 
Dzięki przypisaniu rangi do każdej z wartości zmiennych objaśnianych i objaśniających możliwe stało się obliczenie współczynnika korelacji rang Spearmana. Ze względu na brak rang wiązanych możliwe było wykorzystanie wzoru (Aczel 2000, s. 742):

$$
r_{s}=1-\frac{6 \Sigma_{\mathrm{i}=1}^{\mathrm{n}}\left(R_{x_{i}}-R_{y_{i}}\right)}{\mathrm{n}\left(\mathrm{n}^{2}-1\right)}
$$

gdzie:

$R_{x_{i}}$ - ranga zmiennej X dla obserwacji,

$R_{y_{i}}$ - ranga zmiennej Y dla obserwacji,

$\mathrm{n}^{y_{i}}$ - liczba obserwacji,

$r_{s}$ — wartość korelacji rang Spearmana, dla zmiennych X i Y.

\section{Wyniki}

Wartości współczynników korelacji rang Spearmana przedstawia tabela 4.

W kolumnach 4-7 przedstawiono korelacje rang wyliczone między rangami aktywów netto pozyskanych w danym roku (wyrażonych w PLN) a poszczególnymi zmiennymi objaśniającymi. W kolumnach 8-11 przedstawiono korelacje rang obliczone między rangami aktywów netto pozyskanych w danym roku (wyrażonych w procentach wartości aktywów netto danego funduszu na koniec poprzedniego roku) a poszczególnymi zmiennymi objaśniającymi.

Rangi dla kosztów przyporządkowano w kolejności od najniższych kosztów do najwyższych, więc dodatnia korelacja kosztów z pozyskanymi aktywami sugeruje, że niższe koszty oznaczają wyższe napływy. Rangi dla stóp zwrotu przyporządkowano w kolejności od najwyższych stóp zwrotu do najniższych, dodatnia korelacja wskazuje zatem na większe zainteresowanie klientów funduszami o najwyższych stopach zwrotu. Rangi dla aktywów netto przyporządkowano od najwyższych wartości do najniższych, a dodatnia korelacja sugeruje, że większe fundusze (o wyższych aktywach netto) łatwiej przyciągały klientów. 


\begin{tabular}{|c|c|c|c|c|c|c|c|c|c|c|c|c|c|c|c|c|}
\hline \multirow{4}{*}{ 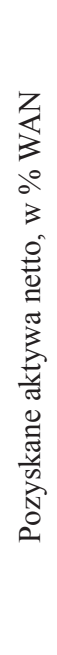 } & 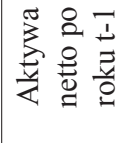 & $\frac{\hat{m}}{\overrightarrow{0}}$ & $\frac{ \pm}{\overrightarrow{0}}$ & $\begin{array}{l}\overrightarrow{\widetilde{N}} \\
\text { ô }\end{array}$ & 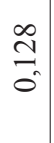 & \begin{tabular}{l}
\multirow{2}{n}{} \\
$n$ \\
0
\end{tabular} & $\begin{array}{l}\text { \& } \\
\stackrel{1}{0}\end{array}$ & $\begin{array}{c}0 \\
\text { m } \\
\hat{0}\end{array}$ & $\begin{array}{l}0 \\
\text { o } \\
0 \\
0\end{array}$ & $\frac{8}{\stackrel{8}{0}}$ & $\stackrel{\widehat{\jmath}}{\stackrel{0}{0}}$ & $\begin{array}{l}\hat{m} \\
\hat{0} \\
\hat{0}\end{array}$ & 穴 & $\begin{array}{l}0 \\
\\
i \\
i\end{array}$ & $\begin{array}{l}\frac{Z}{ \pm} \\
\dot{p}\end{array}$ & $\begin{array}{l}\text { సे } \\
\text { ?े } \\
\text { î }\end{array}$ \\
\hline & 空 & $\underset{\sigma}{\stackrel{N}{\sigma}}$ & 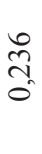 & 항 & 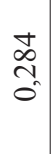 & $\begin{array}{l}\hat{\sigma} \\
\hat{\sigma} \\
0\end{array}$ & $\begin{array}{l}2 \\
\hat{n} \\
0 \\
0\end{array}$ & 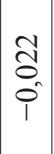 & $\frac{\grave{I}}{0}$ & $\begin{array}{l}\text { f } \\
\text { f } \\
0\end{array}$ & $\begin{array}{l}8 \\
0 \\
0\end{array}$ & $\mid \begin{array}{c}\infty \\
n \\
0 \\
0\end{array}$ & $\begin{array}{l}n \\
\infty \\
0 \\
0 \\
0\end{array}$ & $\begin{array}{l}\text { సે } \\
\text { กิ }\end{array}$ & $\begin{array}{l}\tilde{n} \\
\hat{n} \\
\tilde{\sigma}\end{array}$ & 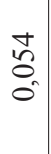 \\
\hline & 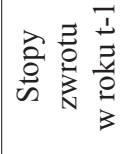 & فنّ & نَّ & فن & 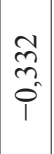 & 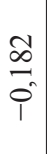 & $\begin{array}{l}\stackrel{2}{1} \\
0 \\
0 \\
1\end{array}$ & $\begin{array}{c}\overrightarrow{1} \\
\infty \\
0 \\
0\end{array}$ & 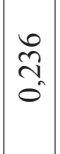 & $\begin{array}{l}\text { N} \\
\text { i } \\
i\end{array}$ & $\frac{a}{2}$ & 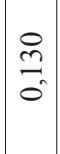 & 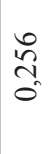 & $\overline{\hat{\sigma}}$ & $\begin{array}{l}n \\
n \\
m^{2} \\
i\end{array}$ & $\stackrel{n}{\stackrel{n}{p}}$ \\
\hline & 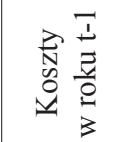 & $\frac{\bar{\infty}}{\rho^{\circ}}$ & $\frac{i}{n}$ & $\begin{array}{l}\text { हे } \\
\text { Oे } \\
\text { i }\end{array}$ & $\begin{array}{l}1 \\
8 \\
0 \\
0\end{array}$ & $\begin{array}{l}\overrightarrow{0} \\
\overrightarrow{0}\end{array}$ & $\begin{array}{l}\infty \\
\varnothing \\
0 \\
0\end{array}$ & $\begin{array}{c}n \\
\infty \\
0 \\
1\end{array}$ & 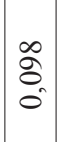 & $\begin{array}{l}0 \\
\infty \\
2 \\
0 \\
0\end{array}$ & $\begin{array}{l}\overline{\mathrm{N}} \\
\stackrel{0}{0}\end{array}$ & 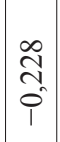 & 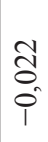 & $\frac{n}{2}$ & $\begin{array}{l}\stackrel{0}{2} \\
\text { m. } \\
0\end{array}$ & $\begin{array}{l}12 \\
\text { in } \\
0 \\
0\end{array}$ \\
\hline & 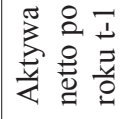 & $\frac{n}{n}$ & $\begin{array}{l}8 \\
\stackrel{9}{0} \\
0\end{array}$ & $\begin{array}{l}0 \\
n \\
2 \\
0\end{array}$ & 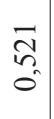 & $\begin{array}{l}\stackrel{\Xi}{0} \\
\text { Oे }\end{array}$ & $\begin{array}{l}\hat{n} \\
\tilde{0} \\
\tilde{0}\end{array}$ & $\begin{array}{l}0 \\
0 \\
0 \\
0 \\
1\end{array}$ & $\begin{array}{l}\tilde{o} \\
\hat{\sigma} \\
0\end{array}$ & $\frac{\bar{n}}{0}$ & 离 & $\mid \begin{array}{l}\infty \\
0 \\
0 \\
0 \\
i\end{array}$ & $\begin{array}{l}\vec{f} \\
\text { ñ } \\
0\end{array}$ & 寺 & $\begin{array}{l}\sigma \\
\sigma \\
\sigma \\
\sigma\end{array}$ & $\begin{array}{l} \pm \\
0 \\
2 \\
0\end{array}$ \\
\hline $\begin{array}{l}3 \\
0 \\
0 \\
0\end{array}$ & 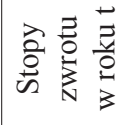 & $\frac{n}{n}$ & 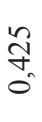 & 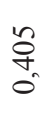 & \begin{tabular}{c}
0 \\
\multirow{2}{*}{} \\
3 \\
0 \\
0
\end{tabular} & $\begin{array}{l}\tilde{N} \\
n \\
0 \\
0\end{array}$ & 吕 & $\begin{array}{c}2 \\
\vdots \\
0 \\
0\end{array}$ & $\begin{array}{l}\tilde{N} \\
\tilde{N} \\
0\end{array}$ & $\begin{array}{l}\text { O } \\
\text { O. } \\
0\end{array}$ & $\overrightarrow{0}$. & $\frac{\vec{n}}{0}$ & $\frac{\circ}{\circ}$ & $\frac{2}{\hat{\gamma}}$ & $\begin{array}{l}0 \\
\infty \\
2 \\
0 \\
0\end{array}$ & $\begin{array}{l}\circ \\
8 \\
0 \\
0 \\
0\end{array}$ \\
\hline 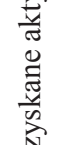 & 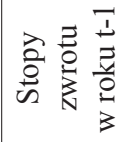 & ن. & فّ & ن. & $\begin{array}{l}\hat{m} \\
\hat{n} \\
\hat{i}\end{array}$ & $\begin{array}{l}\stackrel{2}{\circ} \\
\stackrel{0}{*}\end{array}$ & $\begin{array}{l}\vec{\infty} \\
0 \\
0 \\
0 \\
1\end{array}$ & $\begin{array}{c}8 \\
\stackrel{1}{1} \\
\text { o }\end{array}$ & $\left|\begin{array}{c}\infty \\
0 \\
0 \\
0\end{array}\right|$ & $\frac{\widetilde{O}}{0}$ & $\begin{array}{l}0 \\
8 \\
0\end{array}$ & \begin{tabular}{l}
\multirow{2}{n}{} \\
0 \\
0 \\
1
\end{tabular} & $\begin{array}{l} \pm \\
\Xi \\
0\end{array}$ & $\frac{2}{\circ}$ & $\frac{\tilde{I}}{\stackrel{i}{i}}$ & Õ \\
\hline & 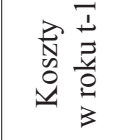 & $\begin{array}{l}\stackrel{0}{\exists} \\
\stackrel{0}{1}\end{array}$ & $\frac{\stackrel{2}{\mathrm{c}}}{\mathfrak{p}^{\prime}}$ & $\begin{array}{l}\overrightarrow{3} \\
\text { o. } \\
\hat{0}\end{array}$ & $\begin{array}{c}n \\
\tilde{n} \\
0 \\
0\end{array}$ & $\begin{array}{l}\vec{z} \\
0 \\
0 \\
0\end{array}$ & $\frac{\stackrel{J}{d}}{0}$ & $\begin{array}{l}\tilde{O} \\
0 \\
0 \\
0\end{array}$ & $\begin{array}{l}\hat{\sigma} \\
\dot{0} \\
0 \\
0\end{array}$ & $\frac{ \pm}{\stackrel{0}{i}}$ & $\begin{array}{l}\overrightarrow{8} \\
0 \\
i\end{array}$ & $\begin{array}{l}0 \\
\mathbb{1} \\
0 \\
0 \\
1\end{array}$ & $\frac{n}{n}$ & $\hat{n}$ & $\begin{array}{l}\stackrel{2}{\widehat{N}} \\
\stackrel{0}{0} \\
1\end{array}$ & $\begin{array}{l}n \\
n \\
0 \\
0 \\
0\end{array}$ \\
\hline & 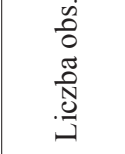 & $\bar{m}$ & $\bumpeq$ & $\bar{m}$ & $\approx$ & 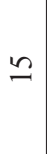 & $m$ & $\tilde{m}$ & $\infty$ & ले & $\hat{n}$ & 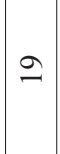 & F & f & $\vec{\sim}$ & $\mathscr{F}$ \\
\hline & 总 & $\begin{array}{l}:=\frac{1}{0} \\
.00 \\
.00 \\
0\end{array}$ & 浩 & $\begin{array}{l}: \bar{\sigma} \\
\frac{\pi}{\pi}\end{array}$ & 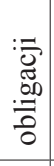 & 漓 & $\begin{array}{l}: \frac{1}{\sigma} \\
\frac{\sqrt{\sigma}}{\sigma}\end{array}$ &  & : & $\begin{array}{l}: \bar{ত} \\
\frac{y}{\pi}\end{array}$ & $\begin{array}{l}:=\frac{1}{0} \\
.000 \\
: 00 \\
0 \\
0\end{array}$ & $: \stackrel{\infty}{\Xi}$ & $\frac{:-\bar{v}}{\frac{\bar{y}}{\pi}}$ & $\begin{array}{l}:-\frac{1}{2} \\
.00 \\
.00 \\
\frac{0}{0} \\
0\end{array}$ & 洗 & $\begin{array}{l}:= \\
\frac{\overline{0}}{\pi}\end{array}$ \\
\hline & 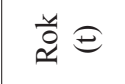 & $\stackrel{\sim}{\stackrel{\sim}{*}}$ & $\stackrel{\sim}{\stackrel{\sim}{\sim}}$ & $\stackrel{\sim}{\stackrel{2}{\sim}}$ & $\stackrel{m}{\stackrel{\sim}{\sim}}$ & $\stackrel{m}{\stackrel{\sim}{\sim}}$ & $\frac{m}{2}$ & $\stackrel{\vec{D}}{\stackrel{\sim}{\sim}}$ & $\stackrel{ \pm}{\stackrel{\sim}{\sim}}$ & $\stackrel{\nabla}{\stackrel{\sim}{\sim}}$ & $\frac{n}{\stackrel{d}{c}}$ & $\frac{n}{\partial}$ & $\frac{n}{2}$ & $\begin{array}{l}0 \\
\stackrel{2}{8}\end{array}$ & $\stackrel{0}{\stackrel{0}{0}}$ & $\stackrel{0}{\circ}$ \\
\hline
\end{tabular}




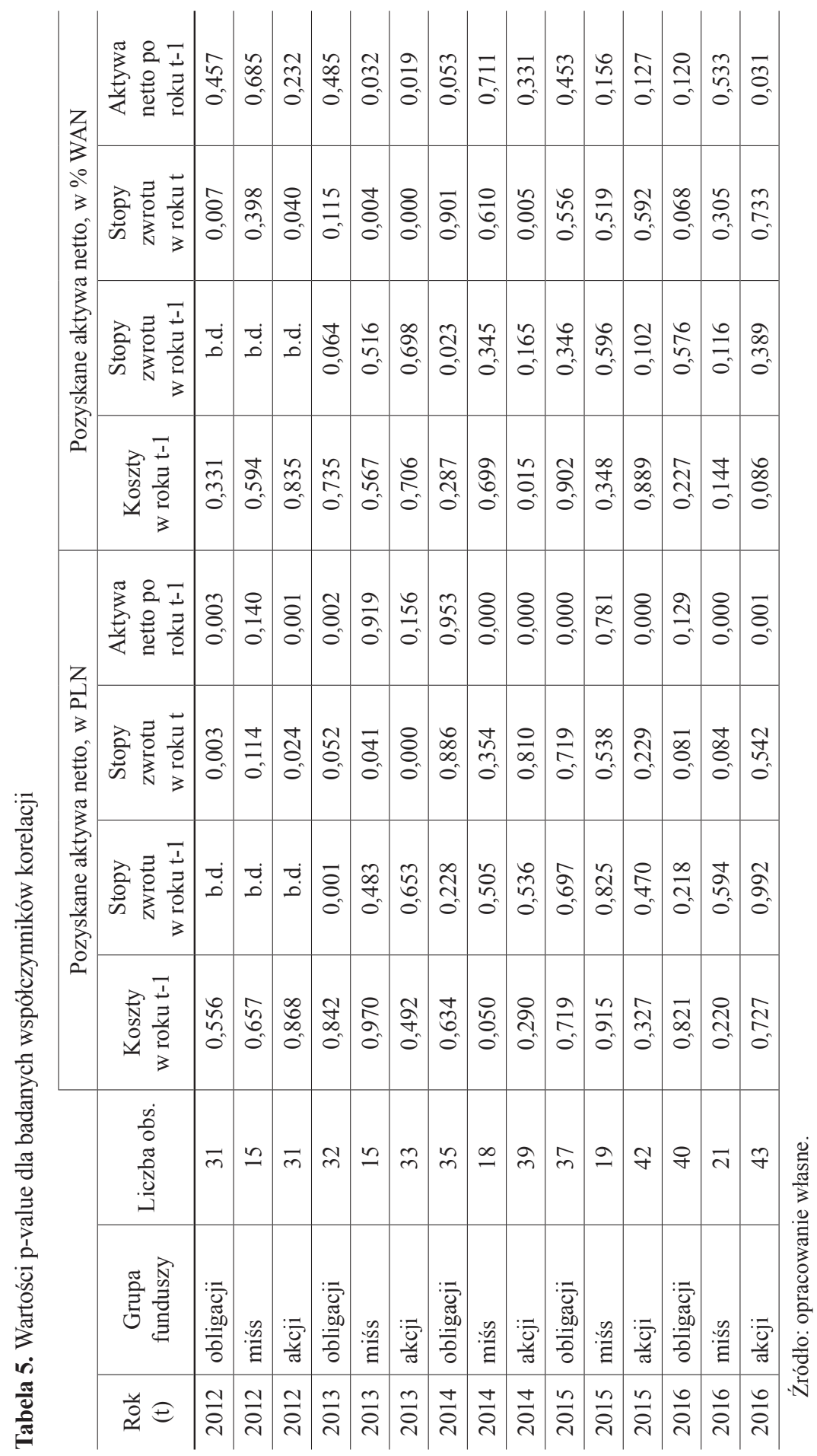


Statystyczną istotność zaobserwowanych zależności zbadano, przeprowadzając test t-Studenta dla każdej z przedstawionych wartości korelacji. Przeprowadzono test dwustronny. Wyniki — wartości p-value — zaprezentowano w tabeli 5.

Tabela 6 przedstawia podsumowanie: informację o tym, czy dana hipoteza została odrzucona dla danego zestawu danych (grupa funduszy w wybranym roku) przy poziomie istotności $\alpha=10 \%$.

Tabela 6. Informacja o odrzuceniu hipotez

\begin{tabular}{|c|c|c|c|c|c|c|c|c|c|c|}
\hline \multirow[b]{2}{*}{$\begin{array}{l}\text { Rok } \\
(\mathrm{t})\end{array}$} & \multirow[b]{2}{*}{$\begin{array}{l}\text { Grupa } \\
\text { funduszy }\end{array}$} & \multirow[b]{2}{*}{$\begin{array}{c}\text { Licz- } \\
\text { ba } \\
\text { obs. }\end{array}$} & \multicolumn{8}{|c|}{ Czy hipoteza została odrzucona? } \\
\hline & & & $\begin{array}{c}\text { Hipo- } \\
\text { teza } \\
\text { nr } 1\end{array}$ & $\begin{array}{c}\text { Hipo- } \\
\text { teza } \\
\text { nr } 2\end{array}$ & $\begin{array}{c}\text { Hipo- } \\
\text { teza } \\
\text { nr } 3\end{array}$ & $\begin{array}{c}\text { Hipo- } \\
\text { teza } \\
\text { nr } 4\end{array}$ & $\begin{array}{c}\text { Hipo- } \\
\text { teza } \\
\text { nr } 5\end{array}$ & $\begin{array}{c}\text { Hipo- } \\
\text { teza } \\
\text { nr } 6\end{array}$ & $\begin{array}{c}\text { Hipo- } \\
\text { teza } \\
\text { nr } 7\end{array}$ & $\begin{array}{c}\text { Hipo- } \\
\text { teza } \\
\text { nr } 8\end{array}$ \\
\hline 2012 & obligacji & 31 & nie & b.d. & tak & tak & nie & b.d. & tak & nie \\
\hline 2012 & miśs & 15 & nie & b.d. & nie & nie & nie & b.d. & nie & nie \\
\hline 2012 & akcji & 31 & nie & b.d. & tak & tak & nie & b.d. & tak & nie \\
\hline 2013 & obligacji & 32 & nie & tak & tak & tak & nie & tak & nie & nie \\
\hline 2013 & miśs & 15 & nie & nie & tak & nie & nie & nie & tak & tak \\
\hline 2013 & akcji & 33 & nie & nie & tak & nie & nie & nie & tak & tak \\
\hline 2014 & obligacji & 35 & nie & nie & nie & nie & nie & tak & nie & tak \\
\hline 2014 & miśs & 18 & tak & nie & nie & tak & nie & nie & nie & nie \\
\hline 2014 & akcji & 39 & nie & nie & nie & tak & tak & nie & tak & nie \\
\hline 2015 & obligacji & 37 & nie & nie & nie & tak & nie & nie & nie & nie \\
\hline 2015 & miśs & 19 & nie & nie & nie & nie & nie & nie & nie & nie \\
\hline 2015 & akcji & 42 & nie & nie & nie & tak & nie & nie & nie & nie \\
\hline 2016 & obligacji & 40 & nie & nie & tak & nie & nie & nie & tak & nie \\
\hline 2016 & miśs & 21 & nie & nie & tak & tak & nie & nie & nie & nie \\
\hline 2016 & akcji & 43 & nie & nie & nie & tak & tak & nie & nie & tak \\
\hline
\end{tabular}

Źródło: opracowanie własne.

Jak widać, hipotezy numer 1 i 5, mówiące o związku napływów do funduszy inwestycyjnych z kosztami ponoszonymi przez uczestników tych funduszy, mogą być odrzucone jedynie w trzech wypadkach z 30: hipoteza numer 1 - tylko dla funduszy małych i średnich spółek w 2014 roku, a hipoteza numer 5 - tylko dla funduszy akcji polskich w 2014 i 2016 roku.

Dla klientów stopy zwrotu osiągnięte przez fundusze w poprzednim roku nie miały istotnego znaczenia, poza trzema wyjątkami dotyczącymi funduszy obligacji (hipotezę numer 2 odrzucono jeden raz, a hipotezę numer 6 odrzucono dwa razy - lecz z dwóch odwrotnych powodów).

Dla klientów ważne okazały się natomiast stopy zwrotu osiągane w roku, w którym podejmowali decyzję o kupnie jednostek uczestnictwa funduszu: hipotezę numer 3 odrzucono w siedmiu przypadkach (z 15), a hipotezę numer 7 - w sześciu. 
Hipotezę numer 4 odrzucono w dziewięciu przypadkach (z 15), udowadniając $w$ ten sposób, że inwestorzy chętniej wybierają duże fundusze. Jednocześnie dzięki przeprowadzeniu testu dla hipotezy numer 8 nie można $\mathrm{z}$ taką samą mocą stwierdzić, że wielkość funduszu ma istotne znaczenie dla tego, jak zmieniają się aktywa funduszu wyrażone procentowo. Aktywa dużych funduszy zmieniają się o większe kwoty niż aktywa małych funduszy (ale już niekoniecznie o większy procent). Wielkość funduszu może wynikać z dostępności tego funduszu - między innymi z wielkości sieci dystrybucji danego funduszu - a nie $z$ tego, że inwestorzy preferują małe czy duże fundusze.

\section{Wnioski}

Choi et al. (2010) dokonali zaskakującego odkrycia: zauważyli, że nawet w wypadku funduszy zarządzanych pasywnie (czyli odzwierciedlających skład indeksu giełdowego) o wyborze funduszu przez klienta decyduje coś więcej niż tylko cena. Obliczyli, że gdyby w 2007 roku inwestorzy wybierali te fundusze odzwierciedlające skład indeksu S\&P500, dla których opłata była najniższa, to oszczędziliby 58\% kwoty wydanej na opłatę za zarządzanie (Choi et al. 2010, s. 1405-1406). Niemal dwukrotne przepłacanie za usługę zarządzania funduszem jest zaskakujące zwłaszcza wtedy, gdy dotyczy grupy funduszy, które nie ponoszą kosztów analizowania inwestycji, a ich główną przewagą wobec aktywnie zarządzanych funduszy są niskie koszty (Reilly, Brown 2001, t. 2, s. 656).

Przeprowadzone przez autorów niniejszego artykulu badanie wydaje się wskazywać, że dla klientów podejmujących decyzje o wyborze funduszu, w który chcą zainwestować, koszty nie mają istotnego znaczenia. Znacznie ważniejsza wydaje się jakość usługi, oceniana na podstawie stóp zwrotu osiąganych przez poszczególne fundusze. Istotniejsza jest również popularność funduszu wśród innych uczestników. Natomiast względnie słaby związek popytu z ceną wydaje się zaprzeczać prawu popytu i podaży.

Możliwe wyjaśnienie tej obserwacji przyniosłyby prawdopodobnie badania nad postrzeganiem swoich inwestycji przez klientów kupujących usługi zarządzania polskimi funduszami inwestycyjnymi. Jeśli klienci funduszy nie koncentrują się na rzeczywistych kosztach usługi, lecz na efektach — czyli na stopie zwrotu osiągniętej już po poniesieniu wszystkich kosztów — to, w ich postrzeganiu, ceną usługi nie jest jej koszt rzeczywisty, lecz koszt alternatywny, wynikający z wybrania konkretnego funduszu. Względnie wysoka stopa zwrotu $\mathrm{z}$ danego funduszu może oznaczać, że w postrzeganiu klienta koszt alternatywny poniesiony przy wybraniu innego funduszu byłby zbyt wysoki. Takie spojrzenie na wybrany fundusz — wyłącznie przez pryzmat osiągniętej stopy zwrotu - thumaczyłoby wybieranie względnie drogich produktów inwestycyjnych. Potwierdzenie tego wniosku wymagałoby przeprowadzenia badania nad postrzeganiem kosztów — zwłaszcza alternatywnych — przez klientów polskich funduszy inwestycyjnych. 


\section{Bibliografia}

Aczel A.D. (2000), Statystyka w zarzadzaniu, Warszawa.

Bogle J.C. (2013), ,, Big money in Boston”: The commercialization of the mutual fund industry, „The Journal of Portfolio Management" 40, s. 133-146.

Cashman G.D., Deli D.N., Nardari F., Villupuram S. (2012), Investors do respond to poor mutual fund performance: Evidence from inflows and outflows, „The Financial Review” 47, s. 719-739.

Choi J.J., Laibson D., Madrian B.C. (2010), Why does the law of one price fail? An experiment on index mutual funds, ,The Review of Financial Studies” 23, s. 1405-1432.

Christoffersen S.E.K., Evans R., Musto D.K. (2013), What do consumers' fund flows maximize? Evidence from their brokers' incentives, „The Journal of Finance” 68, s. 201-235.

Christoffersen S.E.K., Xu H. (2017), Investor attrition and fund flows in mutual funds, „Journal of Financial and Quantitative Analysis" 52, s. 867-893.

Evans R.B. (2010), Mutual fund incubation, „The Journal of Finance” 65, s. 1581-1611.

Ferreira M.A., Keswani A., Miguel A.F., Ramos S.B. (2012), The flow-performance relationship around the world, ,Journal of Banking and Finance” 36, s. 1759-1780.

Ferreira M.A., Keswani A., Miguel A.F., Ramos S.B. (2013), The determinants of mutual fund performance: A cross-country study, „Review of Finance” 17, s. 483-525.

Frazzini A., Lamont O.A. (2008), Dumb money: Mutual fund flows and the cross-section of stock returns, „Journal of Financial Economics” 88, s. 299-322.

Ivković Z., Weisbenner S. (2009), Individual investor mutual fund flows, „Journal of Financial Economics" 92, s. 223-237.

Khorana A., Servaes H., Tufano P. (2009), Mutual fund fees around the world, „The Review of Financial Studies" 22, s. 1279-1310.

Kumar A., Niessen-Ruenzi A., Spalt O.G. (2015), What's in a name? Mutual fund flows when managers have foreign-sounding names, „Review of Financial Studies” 28, s. 2281-2321.

Malkiel B.G. (2013), Asset management fees and the growth of finance, „The Journal of Economic Perspectives" 27, s. 97-108.

Mishkin F.S. (2002), Ekonomika pieniądza, bankowości i rynków finansowych, Warszawa.

Niessen-Ruenzi A., Ruenzi S. (2018), Sex matters: Gender bias in the mutual fund industry, „Management Science" 30.04., https://pubsonline.informs.org/doi/pdf/10.1287/mnsc.2017.2939 (dostęp: 30.06.2018)

O'Neal E.S. (2004), Purchase and redemption patterns of US equity mutual funds, „Financial Management" 33, s. 63-90.

Reilly F.K., Brown K.C. (2001), Analiza inwestycji i zarządzanie portfelem, t. 1-2, Warszawa.

Shrider D.G. (2009), Running from a bear: How poor stock market performance affects the determinants of mutual fund flows, „Journal of Business Finance and Accounting” 37, s. 987-1006.

Sprawozdanie finansowe Quercus SFIO za 2016 rok, https:/quercustfi.pl/Do_pobrania/DoPobrania_Parasolowy/RSFQPSFIOza2016 (dostęp: 30.06.2017).

Zheng L. (1999), Is money smart? A study of mutual fund investors' fund selection ability, „The Journal of Finance" 54, s. 901-933.

Ekonomia - Wroclaw Economic Review 24/2 (2018)

(C) for this edition by CNS 